\title{
Group work in higher education: a mismanaged evil or a potential good?
}

\author{
G P van Rheede van Oudtshoorn* \& D Hay \\ University of Pretoria \& Central University of Technology, Free State
}

\begin{abstract}
This study focuses on the modal proposition that group work in the context of higher education has the potential to enhance learning among students, but has yet to reach its valid zenith of utility value in didactical practice. The particular characteristics of the small group in the context of higher education are described and supplemented by an explication of the small group learning process students partake in. This is followed by a brief examination of structured activities for group work; the assessment of group work; and the implications for the managing of group work in higher education. Empirically, the study explores the perceptions of students regarding group work. Results show that students are positively inclined towards group work and have constructive views regarding the nature of group work as a learning mode. Theoretically speaking, group work has a wealth of potential to offer to the lecturer and the learner. The complexity of the phenomenon leaves the lecturer with no choice but to take great care in the use of group work. The fact that group work is not viewed as a mismanaged evil leaves the door open for further use of this mode of teaching, learning and assessing in higher education.
\end{abstract}

\section{INTRODUCTION}

With the increase in student numbers at South African higher education institutions (coined as the massification of higher education), lecturers have to deal with a proportional increase in workload - particularly on the administrative side. This creates a situation of either adapting or dying in which lecturers have to find ways to deal and cope with the numbers and still maintain academic integrity and standard. For many (Alfers 1994; Huxham \& Land 2000; Gibbs 1998; Harvey, Moon \& Geall 1997) group work provides a solution to the problem of dealing with hundreds of individual students. However, group work is not only about dealing with increasing student numbers, but also forms part of developing students' employability skills. Increasingly employers are seeking graduates with interactive attributes such as interpersonal skills, team working and communication skills, as the workplace demands employees to work effectively in teams, often more than one team at once. Furthermore employees must be able to re-adjust roles from one project situation to another in an ever-shifting work situation (Harvey et al 1997:63). Berg (2003:8)

*Contact person:

G. P van Rheede van Oudtshoorn, Faculty of Economic and Management Sciences, University of Pretoria, Pretoria 0002

E-mail: gp@postino.up.ac.za 
supports this argument by stating that working in a group is vital to students' ability to work successfully in teams in the work force.

Arguments such as the above, and numerous others, have led to a growing interest in the use of team- or group-based learning at all levels of education and training (Livingstone \& Lynch 2002:217).

Group work in itself has the potential to work wonders. It provides answers to not only administrative aspects, but also to the question of teaching students how to actually give form to critical outcomes in educational activities. However, not unlike all other phenomena of great potential, using group work in higher education comes with great responsibility and can backfire on the learning facilitator if it is not well managed. It can become a hollow exercise that misses the aim of facilitating learning. The casual use of group work (or the use of group work purely for the sake of dealing with high numbers of students) is not group work in the true sense, but can easily lead to the misuse thereof.

The study of groups, as well as firsthand experience in group work, cannot be excluded from the student's learning experience. It is not propagated that group work is applicable to every learning outcome (for concurrence see Schein 1988:171), but the participation in group exercises by the learner in higher education is of great importance (as deduced from Gillies' (2002:15) explication of the benefits small-group learning). The reason for this lies in the fact that human beings function in groups. Littlejohn (1999:299) states that cooperation becomes essential in achieving goals as a person moves about in the world. It is only logical that the lecturer or facilitator should take note of the theory behind the use of group work in higher education, as well as the meaning students attribute to the process of learning in groups.

The unique context of higher education imposes its uniqueness on the formation of learning groups. Generally speaking, people join groups either for personal interaction; attraction to group activities and goals; or for the establishment of meaning and identity (Rothwell 2001:54-55). However, in the context of higher education, the primary reason for the formal formation of a group is the planning and execution of learning and assessment activities. Group work in higher education is an idiosyncratic phenomenon that can hardly be described without using a morphological approach to dissect it within its context. A generalised approach to the study and the use of group work in higher education might lead to the facilitator overlooking a concept that might not be found in other studies relating to group work.

\section{DEFINING GROUP WORK}

There are many ways in which to describe the nature of group work in higher education. From an ontological perspective, one can describe the small group as a group of five to seven participants with a collective goal in mind. Yet, the aforementioned seems somewhat simplistic and one can rightfully feel that the true 
nature of the small group is not encapsulated. Rothwell (2001:40), for instance, writes that there is a significant positive correlation between group size and complexity. Cragan and Wright (1999:7) use nine characteristics to define a small group. To find an overarching definition is not an easy task. For Tubbs and Moss (2000:335) education groups are small numbers of people who come together in an attempt to teach or learn something about a given subject. Wertheim (2001) adds another dimension to this definition in defining group work as 'a small number of people with complementary skills committed to a common purpose, specific performance goals, a common working approach and mutual accountability'.

Jacques (2000:1), however, warns that a group is more than a collection of people and should possess at least most of the following qualities, namely collective perception, needs, shared aims, interdependence, social organisation, interaction, cohesiveness and membership. Rothwell (2001:26) links group work to the systems theory in stating that the operations, behaviours and functions which occur within a group can be explained perceptively in terms of the systems theory. There seems merit in defining a small group as a system. Littlejohn (1999:41) provides insight in this regard when describing a system as consisting of four elements (objects, attributes, internal relationships, and a learning environment). The similarities between a system and a small group are obvious.

Moreover, one should remember that group work is a philosophy - working, building, learning, changing, and improving together.

\section{LEARNING PROCESSES AND INFLUENCES IN GROUP WORK}

If it can now be accepted that the nature of the small learning group is complex, it logically follows that the learning process that is supposed to take place within such a group, is even more complex. It would therefore be irresponsible of the learning facilitator to expect students to figure out what and how to learn. The learning facilitator should (at the very least) provide clear didactical instructions as well as an indication of why, how and when the group should achieve a particular outcome. Hoover (2002:191) states that effective teams are effective because they have clearly understood missions or reasons for their existence, accompanied by realistic and attainable goals to be accomplished by meeting concrete objectives. Yet, the facilitator is not the main character in this context; the process that is followed creates an entire realm of learning. Mallard (2002:4) goes as far as to state that group work would seem a waste of time if one does not prepare and follow the four R's of process, namely Reason (providing a reason for the doing of group work to the class), Roles (such as facilitator, recorder, reporter, participant), Rhythm (relating to keeping the group work active, engaging and dynamic) and Response (explicit, overt reflection).

Jacques (2000:78) provides a clear explanation of the process the learning group involves itself in. First, the group members generally draw on knowledge from outside the group in order to process it within and subsequently use it outside 
the group. Second, the group includes someone (the lecturer/tutor) who is typically seen to be responsible for selecting the external knowledge; supervising the learning content's processing in the group; and checking its use beyond the end of the group through some form of assessment.

The responsibility of the learning that takes place within a group weighs heavily on the leader of the group. The problem is that the leader of the group is often more than one person. Who is supposed to take responsibility for the learning process in a group? Is it the lecturer, the tutor, the group leader, or all the group members? It is almost impossible to pinpoint one answer to the aforementioned questions. A contingency plan would work best. In certain groups and in certain situations a particular role-player will have to step to the forefront; in another context, the same role-player will have to play a very subdued role. The shifting responsibility increases the complexity of learning in a group, therefore the responsibilities and roles within the small learning group environment should be clearly defined and understood by all the role-players. If participation enhances the learning process, and leadership increases responsibility of participation, temporary or rotating leadership will encourage individual leadership (Puth 2002:23-24), which in turn will enhance learning. It follows logically that the leadership environment created will greatly influence learning in the context of group work.

Different group dynamics will most certainly influence the learning process. Dynamics such as conformity pressure and comparative social influences (Tubbs \& Moss 2000:337-338) influence group decision-making and will influence the overall group performance. With regard to learning groups, Jacques (2000:77) is of the opinion that the two major areas of aims (with reference to group dynamics) are those concerned with task and with maintenance. The implication is that individual learning will not only take place in the task area, but also in the group maintenance area. Mallard (2002:4) states quite clearly that socialisation is positively related to test grades, and that group work increases socialisation in class. But the dynamics of group work cannot act as a source of information and learning if the group members are blissfully unaware of the underlying theories, paradigms and concepts of group work. Sonnier-York and Stanford (2002:41) state that first of all cooperative learning must be taught, otherwise students may not know how to engage in the cooperative learning process. Miglietti (2002:112-113) strongly recommends a group orientation session, where issues such as the advantages of teams and the essential ingredients for group work are dealt with, be addressed. It is also stated that it is imperative to address the selection of responsibilities of individual group members (which of course relates closely to a definition of group roles). In short, the dynamics of groups is a determining factor in the quality of group results and, as Gillies (202:15) puts it, identifying these variables is crucial to understanding which factors influence learning in cooperative groups and how they influence it. Without knowledge of group dynamics, problems such as (as Brooks \& Ammons (2003) dub it) free riding, conflict management and problem 
solving, might just stifle the learning experience. Perception must surely be viewed as one of these elements involved in the group dynamics.

There are also numerous forces outside of the internal group dynamics that will influence learning processes. For instance, a learning environment that nurtures learning from a group work and group interaction perspective creates a forum for groups to develop in academic quality and would stem members positively toward the experience of working in groups. Hollander (2002:319) argues that we should see class discussions as a collective process where discussion is accomplished by groups, not individuals. Wadoodi and Crosby (2002:243) even recommend paying attention to the physical environment in order to increase a perception of the promise of open interaction. This perspective is of particular relevance, especially when taking note of neo-Vygotskian perspectives on experience. Bazerman (2001:174) explains this perspective by stating that, in neo-Vygotskian studies, situational failures are generally found within the organisational arrangements that bring people together, the organisation of the activity, the mismatch of participants' orientations toward the understand of the situation, or the lack of appropriate tools to mediate the activity. The aforementioned reinforces the necessity to explore not only the group dynamics involved, but also the external factors that can be conducive to either success or failure.

\section{STRUCTURED ACTIVITIES FOR GROUP WORK}

Cognisance should be taken that there is a difference between simply having students work in a group and structuring groups of students to work cooperatively. A group of students sitting at the same table doing their own work, but free to talk to one another as they work, is not structured to be a cooperative group, as there is no positive interdependence. Perhaps it could be called individualistic learning accompanied by talking. The specific structure or form that the group's work process takes on will most definitely be determined by the outcome of the learning unit the learners grapple with. The challenge lies in propitiating the outcome of the learning unit with the inevitable outcome of the structured activity. A third party, namely the facilitator, can also influence the structure of the activity.

Group performances may be designed in different formats, ie panel discussions (which are especially helpful in subjects relating to intercultural studies (Varner 2001), symposia, forums or different forms of assessment products leading to performance appraisals (see Hoover 2002:195; Kremer \& McGuiness 1998). Jacques (2000:93-150) suggests a wide range of activities, including seminars, tutorials, game tasks, step-by-step discussion, buzz groups, fishbowl discussions and crossover groups. If the aim of the group is to solve a problem, sources provide a great number of structured activities the group can partake in (see Cragan \& Wright (1999:73-105) as such an example). These range between discussion formats, specific decision-making techniques and problem-solving agenda systems. 
A question often asked by students is why the lecturer uses such a variety of learning activities. The answer is actually quite simple. Jacques (2000:149) mentions that students' learning styles vary and that a different approach to learning is implicit in each of the different activities. It is also stated that students who have experienced a variety of approaches to learning and to human interaction are more likely to achieve increased choice and awareness in ways of working later in life.

A variety of teaching skills would however be useless if the ability to teach students how to function as group members within these different circumstances is absent. Huff, Cooper and Jones (2002) proposes that faculty need to orientate students regarding the elements that contribute to effective group relations, establish strong lines of communication with each group, and even goes as far as to recommend that faculty has to establish clear and enforceable penalties for opportunistic behaviour that violates the trust of other group members.

\section{ASSESSMENT OF GROUP WORK}

Although the assessment of group work touches on an assortment of problems and challenges, it can be accomplished with great academic and didactic care and integrity. Admittedly, it is not an easy accomplishment, but the rewards offered to both students' learning experiences and the lecturer's administrative burden, warrant a serious effort.

The assessment of group work by the assessor is in itself not a difficult task. It is in fact quite similar to the assessment of any other assessment product created by the learner where memoranda, check sheets, etc., are used to mark and assign a mark. Although the group may be considered as an entity, it is illuminating to study the individual experience of members as well (Jacques 2000:2). The problem lies in assigning individual marks to group members. Although this problem has solutions (Brown 1996), the assessor is not always closely enough involved in the actual work process of the group to assess each member's contribution. Groups often struggle to assign a value to individual members' contributions if they are left to use their own discretion.

Anyone who has had the opportunity of working in a group would state that it is impossible to share responsibility, workload and task complexity on an exact and equal basis. Non-participants always have trouble to assign a group mark to each individual student. To make matters worse, the problem of non-participation increases with an increase in the group's size (Rothwell 2001:41). This gives rise to serious ethical and didactical issues in the case of a lecturer trying to assign one single mark to all the group members. A typical scenario is where a nonparticipative student rests on the academic laurels of a hardworking student, or where the hardworking student is indirectly penalised for another student's lack of effort. This is referred to as freeloading, free riding or social loafing (see Albanese \& Van Fleet 1985). 
Although solutions to this problem will vary according to the particular situation at hand, a few are worth mentioning. One solution is to rethink what is assessed. In group work where the assessor is confronted by the task of assigning different marks to individual group members (or even with the assigning of a single mark), one cannot assess the end-product without taking the context and production process of the small group into consideration. It has been proposed (Hoover 2002:195) that classroom group members evaluate themselves (also see Cragan and Wright (1999:282) on self-reporting) in four general areas, namely substantive, procedural, interpersonal, and ethical. In self-evaluation, the criteria used to assess are of great importance and the learners should clearly describe as well as use them with the necessary gravity.

Gatfield (1999:366) proposes the use of peer assessment and states that peer assessment is ideal when trying to capitalise on the effectiveness of group learning, as well as to ensure equity of marks among students. It is admitted, however, that the allocation of marks to students by subject convenors is generally problematic due to a lack of knowledge of the contributions made by individual members of the group. There are ways to ensure that peer assessment is valid. Gueldenzoph and May (2002:9) suggest, among other things, the implementation of formative feedback during collaborative peer evaluation and the formulation of summative feedback at the end of the evaluation.

Another option would be to ask of the learners to provide the assessor not only with the end-product, but also with assessment products depicting minutes, letters, individual perceptions and other additional material that would enable the assessor to measure group dynamics. Cragan and Wright (1999:286) state that this form of direct measurement has been quite successful in the evaluation of small groups in industry.

As in the case of structured activities, a great number of assessment methods are available to the lecturer, depending on what the lecturer wants to have assessed or evaluated. It is a matter of choosing the most suitable method.

\section{THE REASON BEHIND USING GROUP WORK IN HIGHER EDUCATION}

The real reason behind using group work in higher education ought to be the aim to taste the organisational advantages of teamwork in a learning exercise. Hoover (2002:13-17) discusses actual advantages in three forms - products, processes and personnel. Teamwork can lead to an increase in productivity (in higher education this can relate to quality, quantity, or even continuous improvement), whilst the actual learning process might be made more pleasant and involve more opportunities for individual development in comparison to traditional modes of learning. This argument is supported by the fruits of the labour brought on by group work. In this regard Gatfield (1999:366) mentions an empirical study in a higher education setting which demonstrated that students working in groups 
achieved a higher grade point average than those working in a control situation involving individual students.

As stated by Jacques (2000:v), small group discussion has a valuable part to play in the all-round education of students. It allows for a more interactive and participatory learning process than the more formal methods of teaching permit. It should, however, not be accepted as a given that students know how to deal with the dynamics involved in small group learning. Sensitivity and skills in managing group processes should be developed and taught (Schein 1988:162).

\section{THE MANAGEMENT OF GROUP WORK}

There are many factors to be taken into consideration when attempting to manage the group work process. Gender issues can, for instance, play a dominating role in small group dynamics. Rothwell (2001:21) states that, in mixed-sex groups, men's speech consists mostly of task-orientated, instrumental communication. On the other hand, women's speech consists of supportive and facilitative communication. The aforementioned statements are obviously open to debate and will be influenced by cultural orientations, but it does provide an indication that gender differences exist within the small group and need to be managed in order to nurture a complementary relationship between these differences.

Even though students working together in a group may represent more or less the same age group and have enrolled for the same subject, a great deal of diversity management might still need to take place. Some will even say that management is not enough and that diversity should be appreciated and celebrated as a key force in unleashing the true potential of the group (Hoover 2002:44). A great benefit of group work lies in the fact that students are exposed to the points of view propagated by others. This provides an inoculation opportunity for them to defend or refute certain arguments. Even with regard to argumentation, the diversity might be immense. The numbers of communication variables, as well as the extent to which a variable determines interaction in the group (Riddle, Anderson \& Martin 2000:560-563), would differ from group to group. This will increase the complexity of managing the small group. If the group consists of students from different cultures, the management of the group becomes even more complex (Burns 2002).

Perhaps the answer for at least the lecturer lies in careful management of the group work, in addition to empowering the group itself with the competence to manage the group dynamics. It is recommended by Gatfield (1999:371-372) that tutors should offer more private consultation times and allocate more time in tutorials to assist group work. This is in line with the dual nature of group work, namely a focus on the learning outcome as well as on the handling of group dynamics. Yet there is a fine line between students taking responsibility of their learning and their over-dependency on the expert. 


\section{STUDENTS' PERCEPTIONS REGARDING GROUP WORK}

It is always interesting to hear students' reactions to the possibility of having to complete a group project (see Strauss (2001) for some examples). Some students prefer to work alone and cannot or will not try to adapt (see Hoover 2002:139), while some have a strong need for personal, singular achievement. Individuals typifying these different viewpoints find themselves engrossed in conflict when forced to work together. This offers a challenge to the lecturer to move these students out of their comfort zones and into the group learning experience. In order to do this, the lecturer needs to be thoroughly aware of his/her students' perceptions regarding group work.

But do students' perceptions of group work impact positively on group work? A start to answering to the question might be the perspective of Sonnier-York and Stanford (2002:40) who believes that cooperative learning provides students with positive interdependence and individual accountability. An initial positive perception of the group work process might provide a starting point to the building of positive interdependence. Morgan (2003) concluded that perceptions of group support allowed students to be more relaxed and confident during group exams, and perceptions of group members' dependence on each other caused initial anxiety that was later on proved to be unfounded (fears regarding poor preparation by fellow group members were unfounded). Perceptions of how well a group works together might also provide an indication of success. Deeter-Schmelz, Kennedy and Ramsey (2002) concur that when team members work well together, they tend to work considerably harder toward the team goal and are more likely to achieve that goal effectively. They also found that students who believe that their groups met their goals also believe that their teams worked well together. It follows that a perception of 'working well together' would act as a catalyst for at least an initial substantive effort. It also offers some insights as to why a facilitator ought to pay attention to the moulding of teamwork perceptions, and to explore the perceptions of students in order to better equip students with skills needed to work well in teams.

Bazerman (2001:175) states that experience tells us that deep characterological habits and commitments interfere with or facilitate successful unfolding of situations, that people's moods affect their orientation and ability to participate in situations, and that almost all people show some difficulties in living and cooperating with each other. Perception shapes our world and is a determining factor in the development of moods. Without knowledge of the perception held regarding a specific phenomenon by a specific population, we cannot attempt use, manipulate or justify the use of that phenomenon in that specific population.

\section{PROBLEM STATEMENT}

Even though group work is potentially good in theory and must surely seem attractive to the lecturer of classes of, for instance, more than 400 students, a determining factor in the question regarding the use of group work in higher 
education is the perception that students nurture towards group work. These perceptions might not only hold key information about students' attitudes towards group work, but also about the possibilities of enhancing the group work experience. Learning facilitators may not even be aware of the shortcomings or of the areas of excellence of their didactical conduct regarding group work as perceived by their students.

It is in the best interest of teaching and learning to study the perceptions of students in this regard in order to address possible areas of concern and success. It was the latter that propelled the authors to examine the perceptions of students regarding group work. Subsequently, the following secondary objectives were formulated for this article, namely:

- To determine whether or not students feel more positive toward group learning than individual learning.

- Students' perceptions regarding negative group dynamics.

- The preferences of students regarding the format of structured activities they experience in group work.

- Students' perceptions regarding the utility value of group work.

- If students feel positive about the assessment practices regarding group work.

\section{Research population and sampling}

The sample was extracted from a population consisting of 560 second-year students and 12 honours students in Communication Management at the University of Pretoria. A sample of 300 respondents participated in the study.

A non-probability sample was used and specifically so a purposive sample, because the respondents had to have been exposed to both individual and group work as didactical practice in higher education. A purposive sample includes subjects selected because of specific characteristics (Wimmer \& Dominick 1994:67) in order to collect data which will aid in the reaching of the research objectives.

Because of the fact that students in the Faculty of Economic and Management Sciences at the University of Pretoria are all exposed to both individual and group work by their second-year, students in Communication Management were targeted in the sampling process.

\section{Method of data collection and analysis}

A questionnaire with closed-ended questions, characterised by a limited number of options (Babbie \& Mouton 2001:233), was used to collect data. The questionnaire consisted of 16 questions (closed-ended questions, Likert scales and ordinal value scales). In order to force an opinion from the respondents, a 'neutral' option on the Likert scale was not provided. The questionnaires were completed anonymously and collected immediately on completion thereof. The data was elucidated in frequency tables (univariate analysis). 


\section{RESULTS}

Out of the total of 300 respondents $(\mathrm{N}=300), 20 \%(\mathrm{~N}=60)$ did not give an indication of the number of years they had been studying at an institution/ institutions of higher education. The rest of the respondents answered as follows:

The majority of the respondents who answered this question $(51,7 \% ; \mathrm{N}=124)$ were second-year students, followed by third-year students $(35,8 \% ; \mathrm{N}=86)$. It can therefore be assumed that the great majority of the respondents were undergraduate students.

Table 1: Years of study $(\mathrm{N}=240)$

\begin{tabular}{|c|c|c|}
\hline One year & $1,3 \%$ & $\mathrm{~N}=3$ \\
\hline Two years & $51,7 \%$ & $\mathrm{~N}=124$ \\
\hline Three years & $35,8 \%$ & $\mathrm{~N}=86$ \\
\hline Four years & $9,6 \%$ & $\mathrm{~N}=23$ \\
\hline Five years & $0,8 \%$ & $\mathrm{~N}=2$ \\
\hline Six years & $0,4 \%$ & $\mathrm{~N}=1$ \\
\hline Seven years & $0,4 \%$ & $\mathrm{~N}=1$ \\
\hline
\end{tabular}

Positive feelings about group work

The majority of the respondents felt positive about group learning, as 73,3\% agreed that group learning led to a better understanding of the academic content of a module. When pitched against individual learning, the respondents still felt positive about group learning. The hiatus, however, was relatively small $(59,0 \%$ positive, $40,4 \%$ negative).

Table 2: Group versus individual learning

Statement 1: Group work leads to a better understanding of the academic content of a module.

Statement 2: I can remember academic content dealt with in groups better than academic content which I dealt with on my own.

\begin{tabular}{|c|c|c|c|c|c|}
\hline Statement & $\begin{array}{c}\text { Strongly } \\
\text { disagree }\end{array}$ & Disagree & Agree & $\begin{array}{c}\text { Strongly } \\
\text { agree }\end{array}$ & $\begin{array}{c}\text { Missing (no } \\
\text { response) }\end{array}$ \\
\hline 1 & $6,3 \%$ & $20,0 \%$ & $48,3 \%$ & $25,0 \%$ & $0,3 \%$ \\
\hline 2 & $7,7 \%$ & $32,7 \%$ & $43,7 \%$ & $15,3 \%$ & $0,7 \%$ \\
\hline
\end{tabular}


Perceptions regarding negative group dynamics

The results showed that group domination by a single group member was not perceived as a problem and that students felt willing to contribute to group discussions. This provides an interesting dialectic between a collective effort and individual contributions. There seems to be a golden mean between what is viewed as individual and group work. The lack of perceived domineering behaviour obviously correlates well with the willingness to contribute.

Table 3: Perceptions: Negative group dynamics

Statement 1: The groups I belonged to were usually dominated by one person.

Statement 2: I do not participate in group discussions because I am afraid of being perceived as being stupid.

\begin{tabular}{|c|c|c|c|c|c|}
\hline Statement & $\begin{array}{c}\text { Strongly } \\
\text { disagree }\end{array}$ & Disagree & Agree & $\begin{array}{c}\text { Strongly } \\
\text { agree }\end{array}$ & $\begin{array}{c}\text { Missing (no } \\
\text { response) }\end{array}$ \\
\hline 1 & $19,7 \%$ & $43,3 \%$ & $21,7 \%$ & $12,7 \%$ & $2,7 \%$ \\
\hline 2 & $63,3 \%$ & $23,3 \%$ & $8,0 \%$ & $5,0 \%$ & $0,3 \%$ \\
\hline
\end{tabular}

A small number of the respondents seemed to have overcome the complexity of the last variable on the questionnaire. From the responses that were collected, it was clear that conflict which caused groups to split $(15,7 \%)$ and, to a lesser extent, the fact that none of the group members took on the responsibility of leadership $(8,0 \%)$ caused the highest frequency of typical obstacles in the effective functioning of the group. It contrasts with the fact that the problem 'Individual group members did not do what was expected from them' was perceived to have the lowest occurrence $(12,7 \%)$ when compared to all the other problems.

Table 4: Frequency of problems in group work

\begin{tabular}{|c|c|c|c|c|c|c|}
\hline \multirow[t]{2}{*}{ Problem } & \multicolumn{6}{|c|}{$\begin{array}{c}\text { Rank order }(6=\text { highest occurrence; } \\
1=\text { lowest occurrence) as } \% \text { of total } \\
\text { sample }\end{array}$} \\
\hline & 6 & 5 & 4 & 3 & 2 & 1 \\
\hline $\begin{array}{l}\text { Individual group members did not do } \\
\text { what had been expected from them }\end{array}$ & $3,0 \%$ & $3,7 \%$ & $3,0 \%$ & $4,7 \%$ & $6,0 \%$ & $12,7 \%$ \\
\hline $\begin{array}{l}\text { Nobody took on the responsibility of } \\
\text { being the leader }\end{array}$ & $8,0 \%$ & $4,3 \%$ & $4,7 \%$ & $6,3 \%$ & $5,7 \%$ & $5,7 \%$ \\
\hline
\end{tabular}




\begin{tabular}{|l|c|c|c|c|c|c|}
\hline $\begin{array}{l}\text { Personality clashes hampered the } \\
\text { group's productivity }\end{array}$ & $0,7 \%$ & $9,7 \%$ & $6,7 \%$ & $5,0 \%$ & $5,7 \%$ & $6,0 \%$ \\
\hline $\begin{array}{l}\text { Poor communication among group } \\
\text { members }\end{array}$ & $3,3 \%$ & $4,3 \%$ & $9,3 \%$ & $7,7 \%$ & $6,7 \%$ & $2,0 \%$ \\
\hline $\begin{array}{l}\text { The group as a whole did not know } \\
\text { what it was supposed to do }\end{array}$ & $1,7 \%$ & $7,0 \%$ & $8,0 \%$ & $5,0 \%$ & $6,3 \%$ & $5,3 \%$ \\
\hline Conflict caused the group to split up & $15,7 \%$ & $4,3 \%$ & $3 \%$ & $3,3 \%$ & $5,3 \%$ & $3,0 \%$ \\
\hline
\end{tabular}

(Note that $33,7 \%$ of the sample responded to this variable.)

Preferences regarding the format of structured group work activities

The strongest preference seems to be towards becoming a participant in the class $(67,7 \%$ of the respondents indicated their positive feeling regarding this variable), which contrasts with the traditional model of the lecturer lecturing and students being passive listeners. Students seem to definitely prefer the interactive atmosphere inherent in group work during classes (indicated by a $61,0 \%$ affirmative response). An obvious preference towards creative group exercises $(64,7 \%)$ was also noted.

Table 5: Format of structured group activities

Statement 1: I like the class atmosphere in which group work takes place better than the class atmosphere when a lecture is given by the lecturer.

Statement 2: Group work makes me feel like a participant in class and not like just another face in the crowd.

Statement 3: I have learned more from group exercises which focus on creativity (games, role-playing) than from group exercises that focus on comprehensiveness (eg literature studies, case studies).

\begin{tabular}{|c|c|c|c|c|c|}
\hline Statement & $\begin{array}{c}\text { Strongly } \\
\text { disagree }\end{array}$ & Disagree & Agree & $\begin{array}{c}\text { Strongly } \\
\text { agree }\end{array}$ & $\begin{array}{c}\text { Missing (no } \\
\text { response) }\end{array}$ \\
\hline 1 & $12,7 \%$ & $26,3 \%$ & $44,7 \%$ & $16,3 \%$ & $0 \%$ \\
\hline 2 & $7,7 \%$ & $24,3 \%$ & $50,0 \%$ & $17,7 \%$ & $0,3 \%$ \\
\hline 3 & $8,7 \%$ & $26,0 \%$ & $43,0 \%$ & $21,7 \%$ & $0,7 \%$ \\
\hline
\end{tabular}


Respondents strongly indicated $(84,4 \%)$ that the ideal number of group members for group work should range between no fewer than three and no more than six, with the strongest preference $(53,4 \%)$ for groups consisting of three to four members.

Table 6: Ideal group size $(\mathrm{N}=294)$

\begin{tabular}{|l|c|c|}
\hline \multicolumn{1}{|c|}{ Group size } & \% of responses & $\mathrm{N}$ \\
\hline 2 members & $8,8 \%$ & $\mathrm{~N}=26$ \\
\hline 3-4 members & $53,4 \%$ & $\mathrm{~N}=157$ \\
\hline 5-6 members & $31,0 \%$ & $\mathrm{~N}=91$ \\
\hline 7-8 members & $5,1 \%$ & $\mathrm{~N}=15$ \\
\hline 9-10 members & $0,7 \%$ & $\mathrm{~N}=2$ \\
\hline More than 10 members & $1,0 \%$ & $\mathrm{~N}=3$ \\
\hline
\end{tabular}

With regard to the role/function that respondents felt they fulfilled in groups, three roles/functions stood out, namely organising task delegation $(20,3 \%)$, creative thinking $(19,9 \%)$, and giving information to the group (19,5\%).

Table 7: Role/function in group $(\mathrm{N}=241)$

\begin{tabular}{|l|c|c|}
\hline \multicolumn{1}{|c|}{ Role/function } & \% of responses & $\mathrm{N}$ \\
\hline Giving information to the group & $19,5 \%$ & $\mathrm{~N}=47$ \\
\hline Seeking information for the group & $10,8 \%$ & $\mathrm{~N}=26$ \\
\hline $\begin{array}{l}\text { Summarising information gathered by the } \\
\text { group }\end{array}$ & $14,1 \%$ & $\mathrm{~N}=34$ \\
\hline Organising task delegation & $20,3 \%$ & $\mathrm{~N}=49$ \\
\hline Releasing tension & $5,8 \%$ & $\mathrm{~N}=14$ \\
\hline Creative thinker & $19,9 \%$ & $\mathrm{~N}=48$ \\
\hline Motivating other group members & $5,8 \%$ & $\mathrm{~N}=14$ \\
\hline Silent observer & $3,7 \%$ & $\mathrm{~N}=9$ \\
\hline
\end{tabular}


Perceptions regarding the utility value of group work

The respondents noted quite clearly $(61,3 \%$ agreed and $9,7 \%$ strongly agreed) that lecturers explained, based on mastering the academic content and outcomes of the module, what the relevance of group work was in contrast to individual assignments.

As with the last variable on the questionnaire, a small number of the respondents answered the penultimate variable. Both questions had the same format. The low response rate is perhaps an indication that the format was either too complex or required too much effort from the respondents. As indicated in Table 8 , the small number of responses to the question requiring the ordinal arrangement of learning outcomes that group work helped to attain, was evenly spread. Except for the indication that group work did not help with the enhancement of interpersonal communication skills, the data did not provide a clear tendency among the responses of the students.

Table 8: Learning outcome group work helped to attain

\begin{tabular}{|l|c|c|c|c|c|c|}
\hline \multirow{2}{*}{ Learning outcome } & \multicolumn{5}{|c|}{$\begin{array}{c}\text { Rank order (6 = most applicable; } \\
\text { (1) least applicable) as \% of total sample }\end{array}$} \\
\cline { 2 - 7 } & $\mathbf{6}$ & $\mathbf{5}$ & $\mathbf{4}$ & $\mathbf{3}$ & $\mathbf{2}$ & $\mathbf{1}$ \\
\hline $\begin{array}{l}\text { An understanding of the academic } \\
\text { content of the module }\end{array}$ & $7,0 \%$ & $5,7 \%$ & $4,7 \%$ & $5,7 \%$ & $7,7 \%$ & $5,7 \%$ \\
\hline $\begin{array}{l}\text { The ability to think critically about } \\
\text { the academic content of the module }\end{array}$ & $3,7 \%$ & $5,7 \%$ & $7,0 \%$ & $9,0 \%$ & $6,0 \%$ & $4,7 \%$ \\
\hline $\begin{array}{l}\text { Personal growth through self-discov- } \\
\text { ery and self-disclosure }\end{array}$ & $8,7 \%$ & $7,7 \%$ & $4,7 \%$ & $5,0 \%$ & $5,7 \%$ & $4,0 \%$ \\
\hline $\begin{array}{l}\text { Enhanced interpersonal communica- } \\
\text { tion skills }\end{array}$ & $3,0 \%$ & $2,7 \%$ & $7,3 \%$ & $4,7 \%$ & $6,7 \%$ & $12,0 \%$ \\
\hline $\begin{array}{l}\text { Taking greater responsibility in my } \\
\text { own learning }\end{array}$ & $6,0 \%$ & $9,3 \%$ & $4,3 \%$ & $5,3 \%$ & $5,3 \%$ & $5,3 \%$ \\
\hline $\begin{array}{l}\text { Acquiring skills central to my field of } \\
\text { study }\end{array}$ & $7,3 \%$ & $4,3 \%$ & $7,7 \%$ & $6,3 \%$ & $4,3 \%$ & $5,3 \%$ \\
\hline
\end{tabular}

(Note that $36,0 \%$ of the sample responded to this variable.) 
Feelings about assessment practices regarding group work

The experiences of the students (used to form the sample group) with regard to assessment practices included the practice of assigning the group's mark to each individual student in the group without an effort to ascertain the difference in contributions by different group members. With this in mind, the current practice seemed fair $(47,7 \%$ agreed and $16,7 \%$ strongly agreed). A very strong feeling against students assessing fellow students became apparent. (Of the 67,0\% who felt that assessment of group work should only be done by the lecturer/tutor, $31,3 \%$ agreed strongly with the statement.) This was, to a certain extent, supported $(55,0 \%$ disagreed with Statement 3$)$ by the feeling that group members should not decide on individual high and low marks among themselves.

Table 9: Feelings toward assessment practices

Statement 1: In the assessment of group work, the grading of individual group members' contributions is fair.

Statement 2: Assessment of group work should be done only by the lecturer/tutor and not by fellow students in the class.

Statement 3: Group members should decide among themselves which group members obtain high marks and which obtain low marks.

\begin{tabular}{|c|c|c|c|c|c|}
\hline Statement & $\begin{array}{c}\text { Strongly } \\
\text { disagree }\end{array}$ & Disagree & Agree & $\begin{array}{c}\text { Strongly } \\
\text { agree }\end{array}$ & $\begin{array}{c}\text { Missing (no } \\
\text { response) }\end{array}$ \\
\hline 1 & $14,3 \%$ & $21,0 \%$ & $47,7 \%$ & $16,7 \%$ & $0,3 \%$ \\
\hline 2 & $6,0 \%$ & $26,3 \%$ & $35,7 \%$ & $31,3 \%$ & $0,7 \%$ \\
\hline 3 & $24,0 \%$ & $31,0 \%$ & $29,3 \%$ & $15,7 \%$ & $0 \%$ \\
\hline
\end{tabular}

\section{LIMITATIONS}

As Babbie and Mouton (2001:202) state, it is never possible to observe all the actions and actors relevant to the social phenomenon under study. The findings of this study, with its idiosyncratic errors, are to a certain extent bound by context.

On certain questions in the survey, a very low response rate transpired. The questions with the low response rate were, at least on face value, more complex and required a lot more cognitive effort from the respondents. The level of complexity and required effort presented in certain questions therefore provided the study with a limitation.

The study was applied to students in the subject 'Communication Management'. The subject might lend itself to particular applications for the use of group work that might differ from other subjects. Care needs to be taken when generalising these results. First-year students in particular may perhaps not have 
the necessary group management skills to participate in a similar study (in concurrence with Gatfield's (1999:372) conclusions).

\section{CONCLUSION AND RECOMMENDATIONS}

It is obvious that the students surveyed in this study did not view group work as a mismanaged evil and that they felt more positive about group learning than about individual learning. The reasoning that group work is an excellent means of facilitating learning is supported and even complemented by the positive feeling about the learning that takes place during group work. It also seems as if students were comfortable with the group dynamics they had experienced. Perhaps the idiosyncratic context of the student work group in higher education is the cause of this result; the power struggle in other small groups might not be experienced in higher education because of the fact that all the group members are on the same academic level. The short life span of the group (more often than not the group only had to finish a semester project together) could also have been a contributing factor.

It was indicated that group work catalysed a feeling of participation in the class. Since participation eliminates the passiveness of the student, this is a most valuable attribute of group work. In fact, this study shows that students prefer an interactive class atmosphere. It should however be noted that, as Hollander (2002:320) states, students should receive formal or even informal training in how to be an effective discussion participant. The lecturer/tutor will have to rethink didactic exercises to structure them in such a way that students will have to make use of creative thinking to complete them, especially since one of the popular roles/functions in groups seems to be the role of creative thinker. It was encouraging to see that the relevance and potential good of group work had been addressed and explained to the students, even though they did not seem to realise exactly how group work helps to attain certain learning outcomes. It is recommended that the facilitator acquire sufficient knowledge regarding the dynamics of small groups, and work creatively to find a means to transfer this knowledge to learners.

On assessment, it was interesting to note that students felt comfortable with the assignment of the same mark to every group member. It is difficult to identify the reason for this. It might be that group cohesion played a bigger role than the urge to differentiate between individual contributions; there might even be a cultural (collectivistic) influence; or students might have felt that the workload was evenly distributed in the group. Whatever the case might be, it warrants further investigation. The role of the lecturer/tutor is quite clear, namely that only the lecturer/tutor and he/she alone should be the judge of who obtains which mark. Once again, there might be numerous reasons for this feeling among the students surveyed (such as distrust in other students' capabilities to assess or a previous, unpleasant experience encountered by the students), which warrant further investigation. 
Perhaps the greatest factor in establishing effectiveness in group work is the commitment of the individual group member to the success of his/her team (Hoover 2002:191). If the lecturer can nurture the causes of commitment, group work can be even more successful. These causes will vary and further exploration is needed to clarify the nature and determinants of the causes. Another recommendation for future studies into students' perceptions of group work is to change the unit of analysis from the individual student to using the different groups in the class as units of analysis (see Babbie \& Mouton (2001:86) for a discussion on using groups as units for analysis).

It can be said that group work in higher education is definitely not perceived as a mismanaged evil, but the potential good it has to offer has not yet been unleashed in its full force. There is still a gap between the theory behind the use of group work and the actual use thereof in higher education. The fact that it is not perceived as a mismanaged evil leaves the lecturer with fertile soil in which to nurture the use of small groups to teach, learn and assess.

\section{REFERENCES}

Albanese, R \& Van Fleet, D. D. 1985. Rational behaviour in groups: the free-riding tendency. Academy of Management Review 10(2):244-255.

Alfers, H. 1994. Teaching overcrowded classes: Innovations needed. Matlhasedi, 13(3):37-41.

Babbie, E \& Mouton, J. 2001. The practice of social research. Cape Town: Oxford University Press Southern Africa.

Bazerman, C. 2001. Anxiety in action: Sullivan's interpersonal psychiatry as a supplement to Vygotskian psychology. Mind, Culture and Activity 8(2):174-186.

Berg, T. 2003. Group leadership project teaches corporate skills. The Teaching Professor 17(6):8.

Brooks, C. M \& Ammons, J. L. 2003. Free riding in group projects and the effects of timing, frequency, and specificity of criteria in peer assessments. Journal of Education for Business 78(5):268-273.

Brown, S. 1996. Assessing individual performance on group projects. Focus on Learning Problems in Mathematics 18(4):1-7.

Burns, P. 2002. Communication training for IT intercultural work groups: the significance of prepositions. Information Executive 6(2):4-13.

Cragan, J. F \& Wright, D. W. 1999. Communication in small groups: theory, process, skills. Belmont, CA: Wadsworth.

Deeter-Schmelz, D. R, Kennedy, K. N \& Ramsey, R. P. 2002. Enriching our understanding of student team effectiveness. Journal of Marketing Education 24(2):114-124.

Gatfield, T. 1999. Examining student satisfaction with group projects and peer assessment. Assessment \& Evaluation in Higher Education 24(4):365-377.

Gibbs, G. 1998. Learning in teams - a student guide. Oxford: The Oxford Centre for Staff and Learning Development. London: Oxford Centre for Staff and Learning Development.

Gillies, R. M. 2002. The residual effects of cooperative-learning experiences: a two-year follow-up. The Journal of Educational Research 96(1):15-20.

Gueldenzoph, L. E \& May, G. L. 2002. Collaborative peer evaluation: best practices for group member assessments. Business Communication Quarterly 65(1):9-20. 
Harvey, L, Moon, S \& Geall, V. 1997. Graduates' work: organisational change and students' attribute. Birmingham: Centre for Research into Quality, UCE.

Hollander, J. A. 2002. Learning to discuss: strategies for improving the quality of class discussion. Teaching Sociology 30:317-327.

Hoover, J. D. 2002. Effective small group and team communication. Fort Worth: Harcourt College Publishers.

Huff, L. C, Cooper, J \& Jones, W. 2002. The development and consequences of trust in student project groups. Journal of Marketing Education 24(1):24-34.

Huxham, M \& Land, R. 2000. Assigning students in group work projects. Can we do better than random? Innovations in Education and Training International 37(1):17-22.

Jacques, D. 2000. Learning in groups: a handbook for improving group work. London: Kogan.

Kremer, J \& McGuiness, C. 1998. Cutting the cord: student-led discussion groups in higher education. Education \& Training 40(2):44-49.

Littlejohn, S. W. 1999. Theories of human communication. Belmont, CA: Wadsworth.

Livingstone, D \& Lynch, K. 2002. Group project work and student-centred active learning: two different experiences. Journal of Geography in Higher Education 26(2):217-237.

Mallard, K. S. 2002. Group work that works. The Teaching Professor 16(8):4.

Miglietti, C. 2002. Using cooperative small groups in introductory accounting classes: a practical approach. Journal of Education for Business 78(8):111-115.

Morgan, B. M. 2003. Cooperative learning in higher education: undergraduate student reflections on group examinations for group grades. College Student Journal 1(37):40-49.

Puth, G. 2002. The communicating leader. Pretoria: Van Schaik.

Riddle, B. L, Anderson, C. M \& Martin, M. M. 2000. Small group socialization scale: development and validity. Small Group Research 31(5):554-572.

Rothwell, J. D. 2001. In mixed company. Small group communication. Fort Worth: Harcourt College Publishers.

Schein, E. H. 1988. Organizational psychology. Englewood Cliffs: Prentice-Hall.

Sonnier-York, C \& Stanford, P. 2002. Learning to cooperate - a teacher's perspective. Teaching Exceptional Children 34(6):40-55.

Strauss, P. 2001. 'I'd rather vomit up a live hedgehog' - Students and group assessment in mainstream university programs. Prospect 16(2):55-66.

Tubbs, S. L \& Moss, S. 2000. Human communication. Boston: McGraw-Hill.

Varner, I. I. 2001. Teaching intercultural management communication: Where are we? Where do we go? Business Communication Quarterly 64(1):99-107.

Wadoodi, A \& Crosby, J. R. 2002. Twelve tips for peer-assisted learning: a classic concept revisited. Medical Teacher 24(3):241-244.

Wertheim, G. 2001. Surviving the group project. Available at: http://www.bpaosf.bpa.arizona. edu/ dganley/teams.html. Retrieved on 15 February 2003.

Wimmer, R. D \& Dominick, J. R. 1994. Mass media research: an introduction. Belmont, CA: Wadsworth. 